\title{
DOM QUIXOTE E SUA SAGA EDITORIAL: UMA ANÁLISE COMPARADA DE ADAPTAÇÓES GALEGAS E BRASILEIRAS PARA O PÚBLICO INFANTIL
}

\section{DON QUIXOTE AND HIS EDITORIAL SAGA: A COMPARATIVE ANALYSIS OF GALEGIC AND BRAZILIAN ADAPTATIONS FOR CHILDREN}

\author{
Jéssica de Oliveira \\ Universidade Federal de São Carlos, UFSCar, São Carlos, SP, Brasil \\ Luzmara Curcino \\ Universidade Federal de São Carlos, UFSCar, São Carlos, SP, Brasil \\ Marta Neira Rodríguez \\ Facultad de Educación na Universidad de Santiago de Compostela, USC, Espanha
}

\begin{abstract}
Resumo: A análise de adaptações literárias, como parte das produções que constituem hoje o campo literário, pode lançar luz sobre os discursos sobre a leitura e sobre os leitores de um determinado segmento, discursos que circulam e que determinam o que, em geral, se diz sobre essa prática, assim como delimitam os modos adequados de exercê-la. Nosso objetivo, neste artigo, é analisar algumas das representaçôes discursivas do leitor infantil, que se podem identificar em adaptaçôes do clássico Dom Quixote, a saber: O Cavaleiro do Sonho, de Ana Maria Machado, e a coleção Don Quixote e Breogán, de Anxo Fariña.
\end{abstract}

Palavras-chave: Adaptaçôes; Dom Quixote; Análise Comparada; Galícia; Brasil.

Abstract: The analysis of literary adaptations, as part of the productions that today constitute the literary, can shed light on the discourses on reading and on the readers of a certain segment, discourses that circulate and determine what is generally said about this practice, as well as delimit the appropriate ways of exercising it. Our aim in this article is to analyze some of the discursive representations of the child reader in adaptations of the classic Don Quixote, namely: O Cavaleiro do Sonho, by Ana Maria Machado and the Don Quixote and Breogán collection, by Anxo Farińa.

Keywords: Adaptation; Don Quixote; Comparative Analysis; Galicia; Brazil. 


\section{Dom Quixote e seus retornos}

Desde sua primeira publicaçáo em 1605, data já conhecida como um marco inaugural do romance moderno, até os dias de hoje, a obra O engenhoso fidalgo Dom Quixote de La Mancha ou, de modo mais abreviado Dom Quixote, passou por distintos momentos de recepção, reconhecimento, rememoração, como também de recriação. Graças a seu sucesso e a sua circulação universal, como é próprio das obras consideradas clássicas, ela se sacralizou e se banalizou (cf. ANTUNES; CECCANTINI, 2004).

No ano de 2005 comemorou-se o IV Centenário de publicação da obra de Miguel de Cervantes, ocasião em que ocorreram diferentes manifestações em diversos países, com a realização de exposiçôes, de atividades de fomento ao turismo, de eventos acadêmicos e principalmente com publicaçóes ou reimpressóes de ediçôes especiais e comemorativas. A Real Academia Española, em conjunto com a Asociación de Academias de la Lengua Española, publicou uma das ediçôes mais emblemáticas do IV Centenário de publicação do primeiro volume da obra, pela editora Alfaguara, com a participação do renomado filólogo Francisco Rico na coordenação do volume intitulada Don Quijote de la Mancha. No Brasil, de acordo com o catálogo das traduçóes de Dom Quixote estudadas por Cobelo (2009), somente em 2005, cinco editoras publicaram o clássico de modo integral em suas coleçóes, a saber, Editora 34, Martin Claret, Record, L\&PM e Villa Rica; e uma o reimprimiu, a editora Ediouro.

No segmento editorial de Literatura Infantil e Juvenil, no Brasil e na Espanha, multiplicaram-se os lançamentos e relançamentos de adaptaçóes. No que diz respeito ao cenário brasileiro:

entre 2002 e 2008 surgiram trinta novas adaptaçóes, quase a mesma quantidade que o total editado desde 1886, ano da primeira adaptação do Quixote, assinada pelo professor Carlos Jansen. Somente em 2005 foram lançados quinze novos livros, além de doze publicaçôes de ediçóes anteriores, e a partir desse ano aparecem gêneros inéditos na história das adaptaçôes da obra, como quadrinhos, graphic novel e versos de cordel. (COBELO, 2015, p. 71)

Dom Quixote, desde sua primeira edição, vive uma verdadeira saga de reproduçóes, traduçóes, adaptaçóes e leituras. Sua aventura não se intimida com a distância, com o tempo, com seus inumeráveis leitores 
de distintas comunidades de interpretação (FISH, 1992). Parece não haver língua ou cultura que lhe seja indiferente, que não veja nele um texto ao qual retornar. Sua saga atemporal e transnacional também se complexifica em sua apropriaçáo fractal no interior de uma mesma cultura. Suas versóes diversas respondem a uma ampla gama de possibilidades de recepção junto a públicos bem variados. As adaptaçóes infantis e juvenis contemporâneas desse clássico da literatura ocidental são um exemplo disso.

A aposta de que certos textos têm o que dizer a diferentes leitores é uma das características que se atribui, em geral, aos clássicos. Não apenas se pode multiplicar interpretaçóes que deles se fazem, e sempre identificar algo que ainda não foi propriamente dito ou explorado adequadamente sobre aquilo que um dado autor e obra quiseram dizer, tornando-se, por isso, fonte e objeto de comentário ${ }^{1}$ ao longo do tempo.

Esses retornos se potencializam dada a fecundidade do ter o que dizer a seu respeito, sob a forma das diferentes versóes que se dá a um texto, podendo, inclusive, dele se alterar quase tudo: a) pode-se adequar seu léxico diante da inevitabilidade das mudanças linguísticas que transformam em arcaísmos as palavras antes correntes e que o tempo se ocupou de envelhecer e de encomendar seu esquecimento; b) pode-se redimensionar sua extensão e tamanho diante de públicos que se crê disporem de menos tempo, menos fôlego, menos capacidade de concentração, seja em função de sua idade, seja em funçáa de serem mais expostos a outras formas de narrativas mais breves, objetivas, dinâmicas e intensas e com as quais as longas narrativas em livro estabeleceriam uma concorrência mais desigual na disputa por sua atenção e interesse; c) pode-se adaptar seu gênero discursivo, ou seja, realizar mudanças significativas em sua construção composicional, em seu estilo verbal e/ou em seu conteúdo temático (cf. BAKHTIN, 2000), de modo a fazer com que se assemelhe ao de gêneros mais familiares a leitores de segmentos muito distintos daquele para o qual a obra foi inicialmente escrita e concebida.

Assim, uma obra, como a de Cervantes, pode não apenas criar um horizonte do dizível a seu respeito, sob a forma do comentário (tanto o especializado como o leigo), como também pode gerar um tipo de comentário específico sob a forma de um seu retorno peculiar: aquele que consiste em sua reproduçáo adaptada, ainda que em versóes muito distantes de sua identidade formal de origem. Suas versôes mais honestas não pretendem ser, nem se apresentar como sendo fidedignas ao original. Aliás,

1Para Michel Foucault (1999), o "comentário" diz respeito a uma das instâncias da "ordem dos discursos" que atua no controle do que é dito e dizível sobre um texto, uma obra ou autor, ou sobre uma prática. 
a distância entre elas e o original pode ser algo assumido e ostentado sob a pena autoral de adaptadores que, em alguns casos, são também reconhecidos como autores. $\mathrm{O}$ que interessa, nesses casos, é reafirmar a riqueza do texto primeiro, demarcar esse pertencimento simbólico, fazer seu elogio com sua multiplicação generosa em versóes que, por vezes, não guardam quase nenhuma identidade com o texto primeiro.

Esse tipo de deslocamento, como afirma o filósofo Michel Foucault (1999, p. 22), "não é estável, nem constante, nem absoluto", embora os princípios de revisitação de um texto permaneçam, como sendo uma das características amplamente exploradas de alguns gêneros, como aqueles do campo literário. Dom Quixote é, sem dúvida, um desses textos que, graças às formas de sua (re)produção, apropriação e de sua circulaçáo singulares, ao longo da história e de diferentes culturas, fez dessa obra uma narrativa à qual sempre se retorna, de maneiras deferentes ou sacrílegas, mas sempre dependentes e partícipes da construção de seu renome, de sua fama.

É, pois, com base nesse princípio de controle da recepção dos discursos, em especial no que concerne à recepçáo de obras literárias - princípio que é responsável por regular, orientar, autorizar e excluir, em uma dada cultura e período, o que em geral se diz ou se faz com um clássico como Dom Quixote, segundo as regras do campo discursivo-literário (cf. BOURDIEU, 1996), em que as reproduçóes e as recepçóes da obra se inscrevem - que, neste artigo, nos propomos a analisar algumas representaçóes do público infantil indiciadas na forma dada a algumas adaptaçóes dessa obra, dirigidas prioritariamente para este público, em sua produçáo e em sua circulação contemporâneas, em dois cenários culturais, o brasileiro e o galego.

\section{Dom Quixote para os pequenos: adaptaçóes e suas representaçóes dos leitores}

Tal como apresentamos em (CURCINO; OLIVEIRA, 2020), as produçôes literárias infantis e juvenis são, há algum tempo, uma aposta bem-sucedida do mercado editorial. Entre elas, as adaptaçóes de clássicos conquistaram um recente e relativo reconhecimento junto a instituiçóes responsáveis pela formação de leitores, como a escola, ou pela formação de formadores de leitores, como a universidade. Segundo Lajolo e Zilberman (1987), várias mudanças contextuais permitiram a consolidação deste tipo de literatura específica para crianças brasileiras. 
Não é, assim, de se estranhar que, mais do que qualquer época anterior, nos últimos anos, em particular na década de 70 , a produção literária infantil brasileira conte com tantos autores e títulos, que deixam a perder de vista os 605 trabalhos que Lourenço Filho registra no balanço que faz, em 1942, da literatura infantil de seu tempo. (LAJOLO; ZILBERMAN, 1987, p. 124)

Em comparação ao Brasil, na província da Galícia, a consolidação ocorre quase uma década depois, segundo a especialista Blanca-Ana Roig Rechou:

[...] devido às leis que foram postas em vigor a partir da Constituiçấo de 1978, houve um aumento do estímulo à produção [de obras literárias para o público infantil e juvenil], uma vez que a sua presença era obrigatória nas instituiçóes de ensino, o que propiciou o estabelecimento de uma série de normas que levaram as instituiçóes a apoiar e a promover os livros para os mais jovens. (ROIG RECHOU, 2011, n.p., tradução nossa)

Em sua análise da coleção infantil Os primeiros libros dos nenos, a pesquisadora Mónica Domínguez Pérez descreve a importância da década de 1980 para a literatura infantil galega:

Em primeiro lugar, cabe indicar que até 1979 os livros publicados em galego para a infância ou a juventude constituíam um grupo muito reduzido, que em toda sua história mal superava uma centena de exemplares. As traduçōes constituíam entấo uma quarta parte dessa produção, com contribuições significativas. É a partir da obrigatoriedade do ensino oficial do galego - durante 1979-1980 - que começa a aumentar consideravelmente a produção de literatura infantil e juvenil galega e a importância quantitativa das traduçóes. À época, em comparação, os sistemas castelhanos e catalão [de produção editorial de livros infantis e juvenis] já se encontravam bastante desenvolvidos anos antes, ainda que também tenham experimentado o "boom" editorial dos anos 80. (DOMINGUEZ PÉREZ, 2007, p. 2, tradução nossa)

Essas produçôes destinadas ao público infantil e juvenil náo apenas contam hoje com uma importante visibilidade editorial como também com um sistema de circulaçáo amplo, e por vias legitimadas, de sua difusão e validação. No que concerne especificamente às adaptaçôes, isso se deve, entre outras razóes: i) ao reconhecimento cultural gozado de antemão pelos clássicos que são adaptados e que transferem, em alguma medida, sua importância para a versão adaptada; ii) ao papel das instituiçóes de ensino, em sua adoção de certas obras como objeto cultural escolarizável; 
iii) ao reconhecimento de que já dispóem culturalmente alguns nomes de autores nacionais respeitados no campo literário, que assumem a tarefa de adaptação, e assinam essas produçóes.

A análise de adaptações literárias, como produtos culturais legítimos de nosso tempo, e como parte das produçóes que constituem o campo literário (suas obras, atores, espaços de circulação, formas de julgamento e promoção etc.), pode lançar luz sobre os discursos sobre a leitura e sobre os leitores de um determinado segmento. Esses discursos circulam e determinam o que, em geral, se pode e se deve dizer sobre essa prática, assim como delimitam os modos adequados de exercê-la, tal como concebe a Análise do Discurso, conforme Michel Pêcheux (1995) e Michel Foucault (1999). Segundo Roger Chartier (1998), a análise dessas adaptaçóes nos permite depreender certas representaçôes compartilhadas pelos editores, escritores, ilustradores e adaptadores, acerca do perfil leitor daqueles para quem essas adaptaçóes foram produzidas. Assim, em função de quem se pressupóe compor o público leitor de uma dada produçáo literária, nela se pode encontrar esboçadas suas qualidades ou fraquezas, efetivas ou imaginárias, e que podem ser depreendidas a partir da análise de certas estratégias editoriais e de escrita empregadas no processo de adaptação.

Com vistas a analisar algumas dessas representaçóes do leitor infantil, que se podem identificar em adaptaçóes desse clássico ${ }^{2}$, neste artigo, apresentamos uma análise comparativa de duas ediçóes adaptadas de Dom Quixote, uma nacional e outra galega, ambas lançadas no ano de 2005, e voltadas para o público infantil: O Cavaleiro do Sonho, de Ana Maria Machado, da editora Mercuryo Jovem, e Don Quixote e Breogán ${ }^{3}$, de

${ }^{2} \mathrm{Os}$ dados aqui analisados compóem o corpus que estamos estudando em nossa tese de doutorado em andamento, cujo projeto se intitula Dom Quixote no Brasil: um século de adaptaçôes da obra de Cervantes para crianças e jovens, e que conta com apoio da FAPESP (processo 2018/04533-7). A comparação com adaptaçōes galegas desta obra se deve ao estágio realizado na Universidade de Santiago de Compostela, cujo projeto se intitulou Dom Quixote e suas adaptaçōes para o público infantil e juvenil no Brasil e na Galícia: uma análise contrastiva de representaçóes de seus leitores da atualidade, e para o qual também contamos com apoio da FAPESP (processo 2019/10521-4).

${ }^{3}$ Breogán é um personagem mítico celta, conquistador de terras e fundador da cidade espanhola A Coruńa, onde há uma torre e um monumento em sua homenagem. Para mais informaçóes, acesse: <http://www.torredeherculesacoruna.com/index.php?s=91\&l=pt>. Acesso em: $05 \mathrm{de}$ outubro de 2020. O adaptador Farińa, em entrevistas, explicou que sua escolha de inclusão dessa personagem na adaptaçáo que fez de Dom Quixote, visou tanto 'galeguizar' a narrativa, quanto "introduzir uma nova personagem já que os livros não eram uma versão integral do clássico de Cervantes mas uma interpretação do mesmo. Para que esse novo protagonista, um garoto, tivesse peso suficiente me ocorreu tomar emprestado o nome do herói mítico. 
Anxo Farinã, da editora A Nossa Terra.

Esses dois títulos foram destinados prioritariamente ao público infantil. Ambos foram publicados por editoras especializadas neste segmento e foram assinados por reconhecidos autores de literatura infantil. São também obras que, quando de seu lançamento, contaram com uma recepção em nada negligenciável.

A editora Mercuryo Jovem, responsável pela publicação da adaptação brasileira, foi criada em 2001, e é especializada em obras destinadas ao público infantil e juvenil. Essa adaptação foi uma aposta editorial importante, por ser uma forte candidata a cânone escolar e, assim, dispor de grande potencial junto a programas governamentais de aquisição e distribuição gratuita de livros para alunos de escolas públicas e para a constituição dos acervos de bibliotecas públicas e escolares. Essa editora dispóe de um dos catálogos mais amplos de títulos voltados para esse segmento do público brasileiro, de obras que são verdadeiros bestsellers nacionais e que figuram nessas listas de aquisição pelo Ministério da Cultura.

Já a editora galega, A Nossa Terra, fundada em 1987, encerrou suas atividades editoriais em 2010. Foi uma editora especializada em publicar obras com o objetivo de promover a língua e cultura galegas na província. Em seu catálogo, contou com publicaçôes de várias temáticas e para diversos públicos, todas em galego, dispondo de obras sobre a história da Galícia, de biografias de personalidades importantes dessa região, como também de obras de escritores literários locais, especialmente de escritores e ilustradores de literatura infantil e juvenil.

Quanto aos autores, no Brasil, a obra selecionada é assinada por Ana Maria Machado, reconhecida nacionalmente como importante escritora literária, a qual tem dedicado parte considerável de sua produçáo a obras destinadas ao público infantil e juvenil, pelas quais já recebeu prêmios nacionais e internacionais, da envergadura do prêmio literário Hans Christian Andersen, em 2000, conhecido como o Nobel da Literatura Infantil. Por esta adaptação de Dom Quixote, a autora recebeu o título de Leitura Altamente Recomendável, pela Fundação Nacional do Livro Infantil e Juvenil.

Quanto ao escritor galego, Anxo Farińa, além de escritor, ele é também ilustrador reconhecido e premiado no segmento de Literatura Infantil Galega, tendo recebido prêmios como o Merlín de Literatura Infantil 2011,

Dois personagens de diferentes épocas e lugares, unidos em uma mesma história”. Disponível em: <http://www.noticieirogalego.com/anxo-farina-para-min-a-imaxinacion-e-a-maissorprendente-das-facultades-humanas/>. Acesso em: 02 de outubro 2020. 
e o Frei Martín Sarmiento 2013, ambos criados com o objetivo principal de fomentar a leitura e escrita de títulos publicados em galego. Anxo Fariña foi convidado pela editora para produzir a série Don Quixote e Breogán, da qual foi responsável tanto pelo texto, como pela ilustração.

A adaptaçáo brasileira, além do renome da escritora Ana Maria Machado, conta ainda com a fama de um grande nome das artes plásticas brasileiras, o pintor Candido Portinari, responsável pela ilustração. Diferentemente da adaptação galega, as ilustraçôes de Portinari não foram produzidas para esta obra destinada ao público infantil. Elas foram encomendadas, na década de 50, para ilustrar uma tradução de Dom Quixote, produção que só viria à luz nos anos 70, quase duas décadas depois da morte do pintor. Nessa bela ediçáo, as ilustraçōes foram acompanhadas de legendas comentadas de autoria de outro grande e consagrado escritor brasileiro, Carlos Drummond de Andrade.

Por suas carreiras consagradas como escritores e/ou ilustradores, todos estes que se ocuparam dessas adaptaçôes brasileira e galega de Dom Quixote usufruem de uma grande liberdade autoral, sensível nas duas produçóes tanto no que concerne à adaptaçáo linguística da narrativa quanto à sua ilustração. Sua fama e renome junto à crítica literária e cultural e junto ao público leitor, deste e do outro lado do Atlântico, se evidenciam na decisão de ambos os editores de dar o devido destaque a seus nomes nas capas dessas ediçóes. Em ambas as ediçóes, brasileira e galega, esses nomes dos escritores adaptadores e ilustradores não apenas encontram-se com mais destaque do que o do autor Cervantes, como aparecem com exclusividade. Assim, tanto na ediçáo brasileira, Ana Maria Machado e Candido Portinari, quanto na ediçáo galega, Anxo Farińa, são, por sua atividade artística autoral que precede sua atuação como adaptadores, reconhecidos como autores e autorizados a exercer sua criatividade e liberdade de escrita. E eles o fazem nos diferentes planos de expressão de suas versóes adaptadas, seja no que diz respeito às mudanças na forma de expressáo verbal, na definição do enredo, na seleçâao e na disposição em outra ordem dos capítulos, seja na ilustração como meio de expressão narrativo central nessas produçóes. Seus gestos autorais autorizados indiciam-se nas decisóes narrativas que assumem, como naquela adotada pelo escritor galego, de mesclar aspectos da narrativa original com outros de outras histórias, sejam elas inventadas, sejam elas já conhecidas, das personagens originais com outras figuras ficcionais ou históricas da cultura local, estabelecendo, assim, encontros inéditos entre elas e as personagens de Cervantes. 
De modo a refletir sobre essa relativa liberdade autoral que o próprio gênero adaptação autoriza, assim como lançar luz sobre o interesse peculiar, ao longo do tempo e das culturas, por se adaptar essa novela cervantina, vamos nos dedicar à análise de alguns aspectos formais e estéticos dessas duas adaptaçôes, mais pontualmente de sua ilustração, que exemplificam semelhanças e diferenças nos modos adotados para interagir com seu público fim, e assim representá-lo.

\section{Sob os lápis, pincéis e píxeis dos ilustradores: traços e gestos de nosso cavaleiro da triste figura}

Diferentemente do que normalmente ocorre na edição de livros infantis e juvenis, para os quais se contrata ilustradores que trabalham diretamente com o adaptador, quando náo se trata do próprio ilustrador que adapta também o texto em linguagem verbal, nesta edição adaptada brasileira, o editor retorna a ilustraçôes que foram produzidas décadas antes por Candido Portinari para outra edição de Dom Quixote, por fim não publicada.

Além dos 16 desenhos de Portinari, a adaptação contém informaçôes da vida e da obra desses dois gênios separados no tempo, Cervantes e Portinari, um pintor de histórias e um poeta das imagens:

É claro que ainda há muita coisa para se consertar no mundo. E mesmo que tenha melhorado um bocado, nem dá pra dizer que ele vai ficando mais justo. Mas uma coisa náo dá pra negar: tudo fica mais bonito quando artistas como Cervantes e Portinari nos dão de presente um livro como Dom Quixote ou uns painéis como Guerra e Paz. (MACHADO; PORTINARI, 2005, p. 50)

O encontro desses dois artistas não é um acaso. A obra de Cervantes convida à sua reproduçáo em imagem. Ela descreve cenas prenhes de plasticidade. A própria forma antagônica dos corpos das duas personagens principais da novela fornece o mote para a sua reconstruçáo física, assim como o detalhismo da descriçáo dos cenários por onde eles passam e nos quais se passam suas peripécias. Portinari, por razóes de saúde, produz essa série de ilustrações com lápis de cor ${ }^{4}$. O uso desse material se impóe ao traço

${ }^{4}$ Menos por razões técnicas e mais por recomendação médica, o pintor, à época, interrompe o uso de tintas, em função de seus problemas de saúde ligados aos efeitos de uma intoxicação por chumbo, usado na composição das tintas à óleo. Por isso, essa série Dom Quixote, por 
de seus desenhos. Ele se sente criança desenhando as cenas de Dom Quixote. Seu traço artístico parece responder a essa sua percepção de retorno, de volta à infância, ao se intensificar o estilo naïf nessas suas ilustraçóes. No exercício de seu colorido rabiscado, de seus desenhos angulosos, há um artifício que rememoraria o aprendizado da máo infantil, quanto à força e ao sentido dos traços, em seu gesto e desejo de infundir cor ao papel, encobrindo todo e qualquer espaço na folha antes branca.

Entre as ilustraçôes, como a do Quixote de pernas para o ar, com as nádegas expostas ${ }^{5}$, ou a de Sancho Pança sendo jogado para o alto, por uma série de aldeóes ${ }^{6}$, tem-se não apenas a fidedignidade de representação de uma cena quixotesca aludida na obra, mas a inscrição dessa cena em uma série de trabalhos do pintor Portinari, famoso por suas pinturas em que representa brincadeiras infantis, entre elas as cambalhotas e bananeiras.

A semelhança da pintura Meninos brincando, de 1955, e do desenho Dom Quixote às cambalhotas, de 1956, é sensivelmente observável, em diferentes aspectos: no enquadramento de ambos, na pose e localizaçáo da criança e de Quixote no ato ficar de cabeça para baixo plantando bananeira, no lugar ocupado e na forma do corpo e disposição da cabeça do cavalo, na localização do sol, em um, e da lua em outro. Todos esses traços em comum indiciam a intericonicidade (COURTINE, 2013) entre essas representaçóes imagéticas, ou seja, a relação de remissão, de memória, de inscrição em uma série histórica, que se estabelece entre elas e que atua em sua interpretação.

encomenda para uma ediçấo comemorativa da obra, é produzida com lápis de cor, em um estilo provocativo e moderno. Cf, a esse respeito, no site oficial de divulgaçáo de sua obra $<$ www.portinari.org.br>.

${ }^{5}$ Série Dom Quixote, ilustração Dom Quixote às cambalhotas, de 1956, desenho a lápis de cor. Disponível em: <http://www.portinari.org.br/\#/acervo/obra/1221/detalhes>.

${ }^{6}$ Série Dom Quixote, ilustração Sancho Pança servindo de diversáo para os aldeóes, de 1956, desenho a lápis de cor. Disponível em: <http://www.portinari.org.br/\#/acervo/ obra/1217/detalhes $>$. 

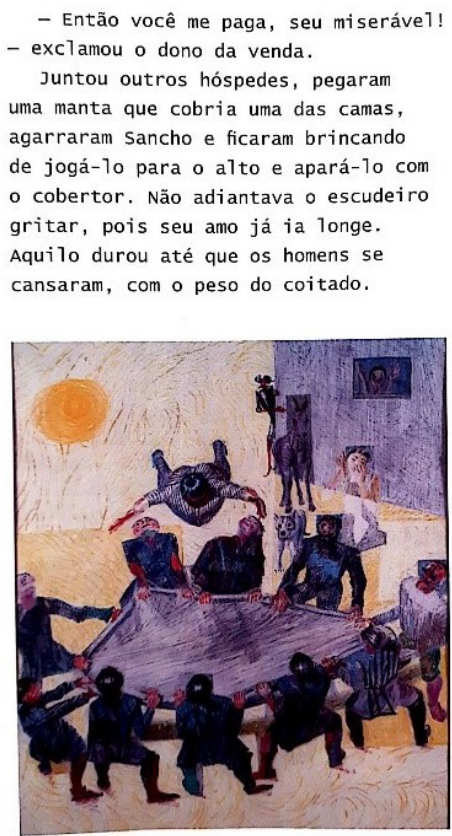

25

Figura 1: O Cavaleiro do Sonho: As aventuras e desventuras de Dom Quixote de la Mancha. p. 25

Fonte: MACHADO; PORTINARI, 2005, p 25.

É um Quixote-menino que ele pinta, cujas loucuras são antes artes de criança. É também uma cena cômica, em que se apresenta um clown, com bigodes táo grandes, se apresentando no picadeiro para o deleite de crianças. Não sem razão, o editor da adaptação seleciona essas imagens, antes feitas para um livro não direcionado para o público infantil. Há nelas não apenas o uso do lápis de cor, que infantiliza, em certa medida, os traços dessas ilustraçôes, como também o eco das produçóes desse pintor que se dedicou a representar cenas de infância, de crianças brincando. Portinari representa a infância, seja no traço infantil dos desenhos feitos a lápis de cor, seja nos gestos e poses infantis das personagens adultas.

A escolha editorial de se valer dos desenhos de Portinari nessa adaptação explora a consonância necessária que deve haver, na composição 
do texto, entre a linguagem verbal e a linguagem imagética. Há livros ilustrados e há livros com ilustração, conforme a distinção descrita por Peter Hunt (2010, p. 233).

A Literatura Infantil toma emprestadas características de todos os gêneros. Mas existe um gênero para o qual ela tem contribuído: o livro ilustrado, que é distinto do livro com ilustração. Essa distinção é, em grande parte, organizacional. Porém, se lembrarmos que a ilustração altera o modo como lemos o texto verbal, isso se aplica ainda mais ao livro ilustrado.

A adaptação brasileira, assim como a adaptação galega, se inscreve no que classifica Hunt (2010) como livro ilustrado. Ainda que por meio de decisões editoriais muito distintas e de recursos técnicos variados, ambas exploram adequadamente as relaçóes semânticas de homologia discursiva (CURCINO, 2011), que contribuem para a produção de efeitos de sentido visados por seus idealizadores junto às expectativas que eles pressupóem serem as do público leitor ao qual são dirigidas essas adaptaçôes.

Embora não tenham sido concebidas para essa finalidade e segmento editorial, as ilustraçôes de Portinari encontram seu lugar próprio nessa edição adaptada. $\mathrm{O}$ que havia de transgressor no humor com que as personagens cervantinas foram representadas ludicamente no lápis de cor do artista, o que havia de ingênuo, fantástico e inesperado nos gestos, poses e cenas quixotescas captados pelo pintor, váo ao encontro do verbo preciso, do léxico simples, da sintaxe clara da representação verbal dos episódios adaptados para a recepçáo desses leitores iniciantes, na escrita de Ana Maria Machado. Há simbiose, há simpatia entre o dito e o mostrado na organização editorial desta edição. Coube à autora Ana Maria Machado dialogar com essas duas obras mestras da literatura e das artes plásticas, e reuni-las em seu texto, reiterando o que nelas haveria de confluência, o que nelas inspiraria o interesse do público iniciante. Coube aos editores e à adaptadora realizar essa produção, tendo no horizonte a preocupação de adequá-la ao interesse institucional, de escolas, bibliotecas, livrarias, na divulgação de um livro adaptado, que tanto apresenta ao público infantil e juvenil um clássico universal da literatura, em sua síntese, em sua essência, quanto a produção de um artista ícone do modernismo brasileiro.

Tendo essa dupla destinação, para o público final e para o público institucional, a adaptação também assume uma função didática em sua apresentação, ao final da edição, quando traz uma espécie de galeria das obras de arte que ilustram o livro. Nessa apresentação, as imagens são 
acompanhadas de referências detalhadas sobre o tipo de material usado na produção de cada uma das ilustraçóes, bem como o ano de sua produção, o museu em que o original se encontra, o seu tamanho e o nome dado pela artista a cada figura.

Nos traços de Portinari, esse leitor iniciante também se depara com cenas semelhantes a fotografias, ou seja, com a depreensão e o congelamento de um momento preciso, flagrado e representado em seu instantâneo. Nesses desenhos do pintor brasileiro se destaca o instante. Como vemos a seguir, diferentemente dessa captação de uma cena, da fixação de um instante, as ilustraçóes que compóem a adaptaçáo galega enfatizam, em certa medida, o movimento, a mudança de estado, a ação, e o fazem com recursos que se assemelham aos empregados para esse mesmo fim na produção de HQ's contemporâneos.

Anxo Farińa, autor, adaptador e ilustrador da coleção Don Quixote e Breogán, explora de maneira expressiva o papel das ilustraçóes. Elas ocupam todas as páginas do livro, e em cada uma delas ocupam a página inteira. Nessa sua predominância como linguagem, elas concedem espaço e acomodam entre seus traços breves passagens verbais, restritas a poucas linhas, localizadas em apenas uma das duas páginas, que o leitor tem diante dos olhos enquanto folheia e lê o livro.

$\mathrm{O}$ autor galego adota uma linguagem em maior consonância com as produçóes atuais e internacionais destinadas ao público infantil e juvenil, sob a forma de desenhos animados, de quadrinhos, ou mais especificamente de animes e de mangás. Do ponto de vista da linguagem verbal, além de mais concisa, e telegráfica, ela também acentua seu caráter oralizado, dialógico e emotivo próprio dos diálogos das HQ's, com a presença significativa de onomatopeias, de uma pontuação expressiva, de apelo à representação gráfica dos alongamentos ou subidas de tom da fala, para conferir maior autenticidade aos diálogos simulados desta ficção. 


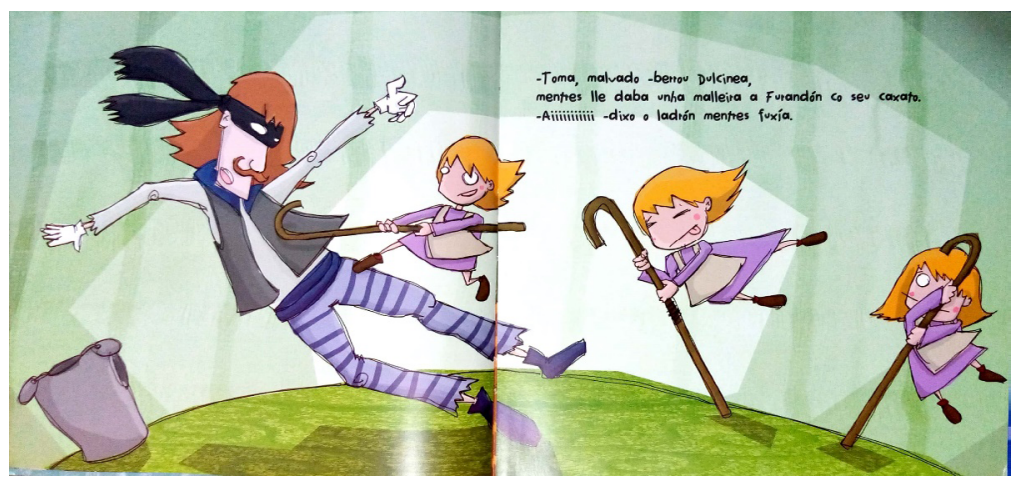

Figura 2: Dulcinea, a nena Cabaleira.

Fonte: Volume 3. Coleção Don Quixote e Breogán. n.p.

- Toma, malvado - gritou Dulcinéia, enquanto batia em Furandón com seu cajado.

- Aiiiiiii - disse o ladrão enquanto fugia. (traduçăo nossa)

Há uma simultaneidade entre o diálogo verbal e a ação representada imageticamente, tal como ocorre nos quadrinhos. Esse efeito de simultaneidade visa restituir o decorrer do tempo, em geral suprimido em uma imagem fixa, apelando para o recurso visual, nesta página, da representação triplicada da personagem Dulcinea, em três movimentos, em três cenas sucessivas, que indicam sua movimentação e ação. Como o traço agentivo é atribuído à personagem Dulcinea, ela é mostrada em ação, enquanto o traço passivo, atribuído à personagem do ladrão, náo exige sua triplicação.

Farińa exerce ainda sua liberdade autoral na composição desta adaptação ao acrescentar açóes não descritas na versão original da obra de Cervantes. Ele insere uma nova personagem, Breogán, que testemunha, vive e interfere nas aventuras de Quixote. Ele também altera os papéis das personagens, atribuindo a Dulcinea o papel de salvar Quixote, Sancho e Breogán de um ladrão chamado Furandón. Altera-se, portanto, o enredo, a ordem, os papéis das personagens e sua linguagem. Acrescenta-se uma personagem central, Breogán, figura mítica, representado como uma criança que, apesar de sua condiçáo infantil, é capaz de ajudar Sancho e Quixote quando os dois intervêm entre dois rebanhos de ovelhas, que Quixote acreditava serem dois exércitos inimigos.

Nos traços de Fariña se enfatizam as personagens em ação, dá-se 
existência a seus movimentos, sempre loquazes. Para isso, as técnicas usadas remetem não apenas ao desenho, como também à colagem, articulados por meio de recursos tecnológicos digitais da atualidade, em um projeto editorial de grande qualidade, com imagens impressas em páginas duplas, com uma cartela de cores bastante chamativa, com o uso (e com a simulaçáo do uso) de técnicas como a da colagem de desenhos, tecidos, linhas e outros objetos que fazem do desenho o resultado de uma bricolagem.

Assim como Portinari, Farińa reproduz técnicas de escrita, de desenho e de arte, em geral empregadas por crianças, em geral ensinadas nos primeiros anos escolares, como a da bricolagem. Alguns traços dos desenhos não são precisos, os recortes usados não têm bordas bem acabadas. Há, nas ilustraçôes, um acúmulo de imagens, de recortes, de cores, como indícios de aspectos próprios de uma estética mais naïf, mais espontânea, primária e, aparentemente, sem técnica. Escreve-se para crianças no estilo de escrita que se atribui a crianças.

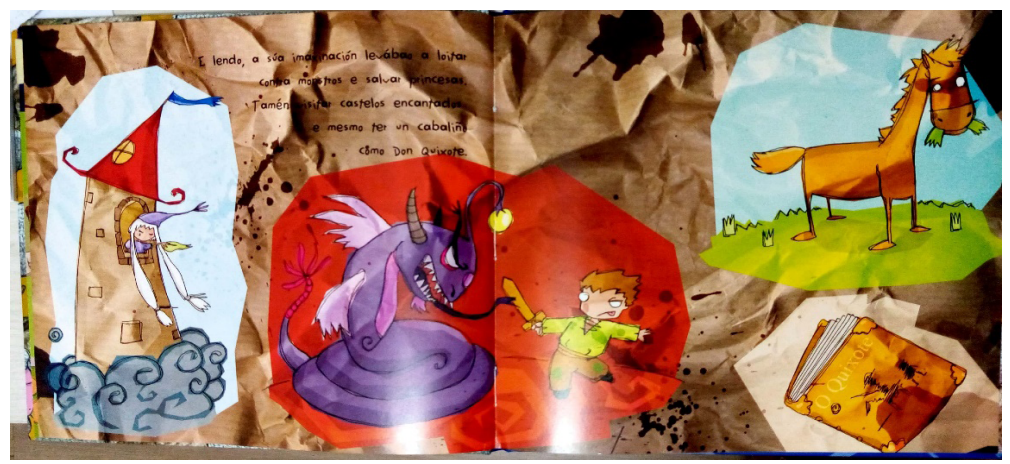

Figura 3: O Exército de ovellas.

Fonte: Volume 2. Coleção Don Quixote e Breogán. n.p.

E lendo, a sua imaginaçâo o levava a lutar contra monstros e salvar princesas. Também a visitar castelos encantados e ainda ter um cavalinho como Dom Quixote. (tradução nossa)

Se não há personagens infantis nas ilustraçôes de Portinari, ele faz dos adultos crianças. No convívio com as personagens adultas, a criança, acrescentada por Fariña na narrativa, também pode acionar a importante identificação do público leitor com a narrativa que lê.

Nos dois projetos editoriais, o leitor infantil está lá também como 
projeção de leitores a serem formados. A densa recorrência aos valores humanísticos na obra de Cervantes, aliados a princípios cristãos, como a defesa dos mais fracos, o senso de justiça, a coragem diante dos desafios ${ }^{7}$, competem para atender um dos objetivos que se crê serem necessários na formação dos sujeitos: o de lhes transmitir valores morais, universais, do bem, da justiça, da honra, da responsabilidade, da amizade, e outros.

Sem os finais típicos moralizantes de algumas obras menores e aligeiradas que se vê com muita frequência incluídas no segmento infantil e juvenil, essas duas adaptaçóes aqui analisadas não infantilizam seus leitores, e, em suas linguagens e formatos distintos, herdam da obra original o compromisso com uma formação profundamente humanizada e respeitosa quanto a seu público leitor, que assume a autoria das imagens, com o lápis de cor, com os riscos e cores acentuados, angulosos, com as colagens etc.

\section{Da bela viagem pelo mundo da leitura}

Dom Quixote é um exemplo incontornável de obra que, ao longo do tempo e em diferentes culturas, foi e continua sendo traduzido e adaptado, para diferentes públicos e em distintas linguagens. Graças às adaptaçóes contemporâneas dessa obra de Cervantes, boa parte do público brasileiro e galego de leitores iniciantes tem travado senáo o único contato, ao menos o primeiro, com este clássico universal. Sua saga editorial, sob as formas mais variadas de sua apropriação, demonstra sua grande força literária. Sua ousadia original, parodística, plena de humor, que dessacralizou, à sua época, gêneros consagrados, é também ela inspiradora e convidativa para que se faça, com sua narrativa, o mesmo gesto. E esse convite de Dom Quixote a uma apropriação criativa, dessacralizadora, parodística tem rendido e ainda renderá muitos frutos.

Prato cheio para adaptadores e ilustradores, as duas obras aqui analisadas, são o exemplo desse convite à subversão que a obra cervantina cochicha nos ouvidos de diferentes artistas. Estes, ao aceitarem participar da empreitada, investem, na produção derivada, tudo aquilo que sabem dos leitores para os quais escrevem, tudo o que pressupóem ser seus gostos, seus interesses, aquilo que lhes chama e prende sua atenção.

Os leitores iniciantes, dos dois continentes, em suas representaçóes

${ }^{7} \mathrm{~A}$ respeito dessa dupla tradição, humanística e cristã, inscrita na obra de Cervantes (cf. CECCANTINI E VALENTE, 2017). 
inscritas nessas adaptações, têm uma predileção por aventuras e se divertem com as adversidades enfrentadas pelas personagens, das quais se exige coragem, ousadia, senso de justiça, resiliência e bom-humor, diante de desfechos muitas vezes absurdos e fantásticos, cujas consequências nem sempre são as esperadas, mas sempre transformadoras. Se a novela cervantina já se sustentava nesses princípios, as adaptaçôes, ainda que encurtem seu enredo e adotem uma outra linguagem, primam por gestar ou intensificar esse gosto pela aventura, pelo sair e desbravar e pelo retornar seguros. Essas são duas constantes e duas necessidades que a vida nos apresenta, e com os quais o acesso à ficção, especialmente na juventude, contribui em sua antecipação e com esta ajuda a construir nossa maturidade e identidade.

No que diz respeito à linguagem verbal, o tratamento dispensado pelos adaptadores visa à atualização do léxico, à simplificação das estruturas sintáticas, com grande apelo à oralidade, à coloquialidade, e no caso da adaptação galega ao recurso predominante ao diálogo e à presença de onomatopeias. Nesta adaptação galega, os protocolos de leitura inscritos no texto pressupóem uma apropriação direta pelo público leitor infantil, cuja leitura não exigiria necessariamente a atuação de um mediador.

Apesar de todos os procedimentos de simplificação e atualização da linguagem empregados na adaptaçáo realizada por Ana Maria Machado, ainda assim, a extensão do texto, seu formato mais próximo daquele da novela cervantina, que intercala o papel do narrador e os diálogos das personagens, aliados ao projeto editorial de emprego das ilustrações de um grande artista plástico brasileiro, cujas biografia e obras são descritas didaticamente, ao final do livro, pressupóem protocolos de leitura segundo os quais a figura do mediador é também requisitada, ainda que alguns leitores um pouco mais iniciados possam lê-lo autonomamente.

No que diz respeito às ilustraçôes, tanto na adaptação galega como na brasileira, elas compóem uma dimensão essencial desse tipo de produção destinada ao público infantil. Em ambas as adaptaçôes, as ilustrações não são meramente decorativas. Elas exercem uma função conjunta com o que é enunciado verbalmente, de modo a, por vezes, precisar o que uma linguagem enunciou, ratificar o que foi enunciado, complementar ou atuar argumentativamente para enfatizar aquilo que seria o mais fundamental do que foi mostrado pela imagem ou dito verbalmente no texto.

A adaptação galega não apresenta paratextos, tal como a adaptação brasileira. Esse é um indício importante do direcionamento da obra galega para um leitor infantil que leria fora da escola e para entreter-se, 
e do direcionamento da obra brasileira para um leitor infantil que, ainda que possa ler essa adaptação fora da escola, o fará prioritariamente pela mediação dessa instituiçáo ou de outros formadores, com o objetivo de lhes apresentar textos essenciais da cultura ocidental e com eles aprender sobre essas personagens emblemáticas, como Quixote, assim como sobre o artista da palavra, Miguel de Cervantes, e o artista da imagem, Candido Portinari.

A presença dos paratextos explicativos acerca da personagem e da vida e obra desses artistas é um indício eloquente dessa representação dos leitores. Se considerarmos que grande parte das crianças brasileiras, dadas as extremas desigualdades sociais de nosso país, não dispóem de acesso a livros de maneira precoce, regular e em ambiente familiar, a escola pública, nesse cenário, é uma instituição chave no fomento à leitura e na garantia do acesso a livros e às narrativas da cultura de prestígio.

Assim, parte significativa da produção editorial para o público infantil e juvenil no Brasil considera essa peculiaridade. No caso da adaptação brasileira, ela responde a essas duas injunçôes: a de garantir uma adaptação de qualidade para o público leitor iniciante e a de responder a essa recepção mediada fundamentalmente pelo papel decisivo da escola pública, da biblioteca escolar e dos professores na garantia do direito à leitura.

Dom Quixote, em sua bela e duradoura saga editorial, continua assim realizando suas peripécias junto a leitores e espaços muito peculiares, e se adequando aos traços e palavras de outros grandes artistas que, com Cervantes, insistem na tarefa de garantir o direito à leitura, à ficção, à literatura, como um direito humano fundamental, tal como nos ensinou o mestre Antonio Candido (2011).

\section{Referências}

ANTUNES, B.; CECCANTINI, J. L. Os clássicos: entre a sacralização e a banalização. In: PEREIRA, R. F.; BENITES, S. A. L. (orgs.). À roda da leitura: língua e literatura no jornal Proleitura. São Paulo: Cultura Acadêmica, 2004. p. 73-89.

BAKHTIN, M. Os gêneros do discurso. In: Estética da criaçáo verbal. São Paulo: Martins Fontes, 2000, p. 277-326.

BOURDIEU, P. As Regras da Arte: Gênese e Estrutura do Campo Literário. Trad. Maria Lúcia Machado. São Paulo: Companhia das Letras, 1996.

CANDIDO, A. O direito à literatura. In: . Vários escritos. Rio de 
Janeiro: Ouro sobre Azul, 2011. Disponível em: <https://culturaemarxismo.files.wordpress.com/2011/10/candido-antonio-o-direitoc3a0-literatura-in-vc3a1 rios-escritos.pdf $>$. Acesso em: 20 outubro de 2020.

CECCANTINI, J. L.; VALENTE, T. A bela loucura da imaginação: ou porque nunca abandonamos Dom Quixote à beira do caminho. In: VAZ, A. E. A.; MARTINS, C. M.; PIVA, M. L. (orgs.). Práticas de ensino de literatura: do cânone ao contemporâneo. Vinhedo: Editora Horizonte, 2017. p. 105-121.

CHARTIER, R. A ordem dos livros: leitores, autores e bibliotecas na Europa entre os séculos XIV e XVIII. Brasília: Editora da UnB, 1998.

COURTINE, Jean-Jacques. Decifrar o corpo: pensar com Foucault. Petrópolis: Vozes, 2013.

CURCINO, L. Princípios de não-homologia entre o verbo e a imagem: breve análise de uma estratégia de escrita da mídia. Estudos Linguísticos, São Paulo, n. 40, vol. 3. set-dez 2011. p. 1398-1407. Disponível em: $<$ https://revistas.gel.org.br/estudos-linguisticos/article/view/1262>. Acesso em: 29 de dezembro de 2020.

; OLIVEIRA, J. A loucura, entre o riso e a surpresa: representaçôes do leitor infantil e juvenil em adaptaçôes de Dom Quixote. Revelli, v. 12, 2020. Disponível em: < https://www.revista.ueg.br/index.php/revelli/article/view/9480>. Acesso em: 29 de dezembro de 2020.

COBELO, S. Historiografia das traduçóes do 'Quixote' publicadas no Brasil: provérbios de Sancho Pança. 2009. 253 f. Dissertação (Mestrado em Letras) - Departamento de Letras Modernas da Faculdade de Filosofia, Letras e Ciências Humanas, Universidade de São Paulo, São Paulo, 2009. (Disponível em: https://teses.usp.br/teses/disponiveis/8/8145/tde-02022010140637/en.php>. Acesso em: 17 de outubro de 2019.)

. Os adaptadores do Quixote mais publicados no Brasil. Traduçáo em Revista 18, 2015. Disponível em: <https://www.maxwell.vrac.puc-rio. br/24848/24848.PDF> Acesso em: 29 de dezembro de 2020.

DOMÍNGUEZ PERÉZ, M. Os primeiros libros dos nenos. Liquids, 1, julho-dez. 2007. Disponível em: https://www.uv.es/liquids/liquids1/articles/ monicado07.pdf. Acesso em: 26 de agosto de 2020.

FARIÑA, A. A aventura dos muíńos. A Nosa Terra, 2005. (Don Quixote e Breogán).

. O dragón voador. A Nosa Terra, 2005. (Don Quixote e Breogán). 
. Dulcinea a nena cabaleira. A Nosa Terra, 2005. (Don Quixote e Breogán).

O exército de ovellas. A Nosa Terra, 2005. (Don Quixote e Breogán).

. O león durmiñón. A Nosa Terra, 2005. (Don Quixote e Breogán). Breogán).

A pousada encantada. A Nosa Terra, 2005. (Don Quixote e FISH, S. Is there a text in this class?. Revista Alfa, São Paulo, v. 36, p. 189206, 1992. Disponível em: https://periodicos.fclar.unesp.br/alfa/article/ view/3919/3600 . Acesso em: 23 de novembro de 2020.

FOUCAULT, M. A ordem do discurso. São Paulo: Edições Loyola, 1999.

HUNT, P. Crítica, Teoria e Literatura Infantil. São Paulo: Cosacnaify, 2010.

LAJOLO, M.; ZILBERMAN, R. Literatura infantil brasileira: história e histórias. São Paulo: Ática, 1987.MACHADO, A. M; PORTINARI, C. O Cavaleiro do Sonho: As aventuras e desventuras de Dom Quixote de la Mancha. São Paulo: Mercuryo Jovem, 2005.

PÊCHEUX, M. Semântica e Discurso: uma crítica à afirmação do óbvio. Campinas: Editora da UNICAMP, 1995.

ROIG RECHOU, B. A literatura infantil e xuvenil galega no século XXI: Seis chaves para "entendela mellor". Alicante: Biblioteca Virtual Miguel de Cervantes, 2011. Disponível em: www.cervantesvirtual.com/nd/ ark:/59851/bmc7p9j8. Acesso em: 26 de agosto de 2020. 